\title{
KobIETA U PROgu ŻYCIA. DoJRZEWANIE do MIŁOŚCI, SEKSUALNOŚCI, PRZYJAŹNI w КовIETACH ZoFII NaŁKOWSKIEJ
}

\section{LITERACKOŚĆ DZIENNIKÓW, AUTOBIOGRAFIZM LITERATURY}

Powieść, której dotyczyć będą niniejsze rozważania, została napisana przez Zofię Nałkowską (1884-1954) u progu jej drogi twórczej. Pierwsza część utworu, zatytułowana Lodowe pola, powstała najpewniej w drugiej połowie 1903 roku i wkrótce zaczęła się ukazywać we fragmentach w „Prawdzie” Aleksandra Świętochowskiego (numery 5-13, rok 1904). W tym czasie pisarka przygotowała dwie kolejne części i postarała się o wydanie całości w 1906 roku pod wspólnym tytułem Kobiety.

Debiutancka powieść Nałkowskiej (wcześniej Nałkowska pisała i publikowała tylko modernistyczne wiersze w pismach warszawskich i krakowskich ${ }^{1}$ ) to „pamiętnik okresu dojrzewania" ${ }^{2}$ utwór o etapie samopoznania i dojrzewania umysłu, pisany o kobiecie, przez kobietę, z kobiecego punktu widzenia. Krytycy w głównej bohaterce powieści, Jance Dernowiczównie dopatrywali się cech samej artystki. Zbieżność doświadczeń Janki oraz jej powieściowej przyjaciółki z umysłowymi, duchowymi problemami i perypetiami młodej pisarki sprawiła, że uznano, iż Nałkowska w Kobietach stworzyła literacki obraz samej siebie ${ }^{3}$. Przypuszczenie to niejako potwierdza wypowiedź samej pisarki:

[...] określiłabym siebie jako realistkę w oddawaniu zdarzeń życia psychicznego. Nie wymyślam nic, nie wyobrażam sobie - tylko układam we wzory szczegóły zawsze tych psychicznych własnych [wyróżnienie - A. K.] przeżyćs.

\footnotetext{
*Anna Kaźmierska - absolwentka filologii polskiej na Uniwersytecie Łódzkim. Na co dzień łączy pasję literaturoznawczą z pracą w agencji reklamowej, gdzie zajmuje się mediami społecznościowymi. Jej zainteresowania badawcze oscylują wokół literatury końca XIX wieku i koncentrują się przede wszystkim na zjawisku dandyzmu (temu zagadnieniu poświęciła swoje prace dyplomowe). Owocem jej literackich zainteresowań są dwie publikacje w tomach pokonferencyjnych: Śmierć upoetyczniona - literackie obrazy śmierci samobójczych oraz Wstręt wobec życia, wstręt wobec śmierci. Rozważania wokót "Śmierci. Studium” Ignacego Dąbrowskiego.

${ }^{1}$ H. Kirchner, Natkowska albo życie pisane, Warszawa 2011, s. 71.

${ }^{2}$ Tamże.

${ }^{3}$ Takie opinie wyrażał m.in. J. Dąbrowski, Nowe książki, „Robotnik” 1927, nr 113, [br. nr. s.]; cyt. za: E. Pieńkowska, Zofia Natkowska, Warszawa 1975, s. 15.

${ }^{4}$ E. Pieńkowska, $d z$. cyt., s. 15.
} 
W opinii kilkunastoletniej Nałkowskiej pisanie Dzienników, dokumentowanie codzienności to sposób opowiadania o życiu. Nałkowska była świadoma, jak silnie literatura uobecniała się w jej życiu, jak wielkie znaczenie miała perspektywa artystyczna w odbieraniu wrażeń dnia codziennego. Mimo to była przekonana, że w dziennikach nie ma literatury. Nałkowska stwierdziła: „O ile żyję literacko, o tyle piszę ten dziennik, żyjąc" się więc, że dla autorki Granicy literatura to twór kompletny, dopełniony, dziennik zaś dawał większą swobodę, pozwalał utrwalić swoistą „nieidealność” codzienności, miał raczej formę szkicu, notatki.

Nałkowska nie uważała się za literatkę, która potrafiłaby pisać powieści i nowele. Wydawała się pewna, że pomimo oczytania nigdy nie nabierze wykształcenia literackiego i nie stanie się kreatorką światów fikcyjnych ${ }^{6}$. Szybko okazało się jednak, że paradoks Wilde'a, mówiący o mimetycznej funkcji życia wobec sztuki, dotyczył także autorki Kobiet. Odżegnując się od tworzenia literatury, skupiając się na zapisie prawdziwego życia w Dziennikach, pisarka realizowała potrzebę artyzmu, udowadniła wrażliwość na sztukę w codzienności, a tym samym nieświadomie, transponując czystą codzienność na karty dziennika, tworzyła sztukę. Dzienniki to nie tylko pamiętnik, w którym Nałkowska-pisarka dokumentowała to, co przeżywała Nałkowska jako kobieta, człowiek, twórca, córka, narzeczona. Choć sama artystka chciała postrzegać swój dziennik jako zapis codzienności, współcześni czytelnicy i badacze akcentują dipolowy charakter twórczości pamiętnikarskiej pisarki. Hanna Kirchner zauważyła, i uwaga ta wydaje się jak najbardziej uzasadniona, że „diarystyka Nałkowskiej ma [...] byt podwójny: archiwum życia i potoku prozy artystycznej”

Ten binarny charakter Dzienników (a właściwie - życia i literatury w ogóle) stopniowo uświadamiła sobie także autorka. Jej poglądy stopniowo uległy zmianie — w sierpniu 1903 roku Nałkowska stwierdziła, że dziennik staje się dla niej „bezużyteczny" ${ }^{\prime}$. Pisarka dopuściła do głosu swoją tożsamość jako prozatorki i doszła do wniosku, że chce tworzyć literaturę?

Powiązanie z Dziennikami stanowiło punkt wyjścia do późniejszej drogi twórczej pisarki, a szczególnie początków kształtowania się Zofii jako literatki. Jak pisała Hanna Kirchner, zapewne wkrótce po owym oświadczeniu o woli i mocy pisania powieści i nowel, czyli tego, czego chciała tak uniknąć, patrząc na wysiłek naukowy ojca i do czego z początku się nie poczuwała, Nałkowska przystąpiła do pisania Lodowych

\footnotetext{
${ }^{5}$ Z. Nałkowska, Dzienniki 1899-1905, wstęp i opracowanie H. Kirchner, t. 1, Warszawa 1975, s. 196.

${ }^{6}$ H. Kirchner, Wstęp, [w:] Z. Nałkowska, Dzienniki 1899-1905, t. 1, Warszawa 1975, s. 7.

${ }^{7}$ H. Kirchner, Wstęp. Szkic sangwina, [w:] taż, Natkowska albo..., Warszawa 2011, s. 8.

${ }^{8}$ Z. Nałkowska, Dzienniki 1899-1905, s. 348.

${ }^{9}$ Szczegółowo ten proces samouświadomienia Nałkowskiej opisała Hanna Kirchner we wstępie, ale ze względu na to, że Dzienniki stanowią jedynie punkt wyjścia do rozważań o powieści Kobiety, w tym miejscu nie zostaną przywołane czynniki, jakie się na ten proces złożyły. Odesłać można jedynie do fragmentu: H. Kirchner, Wstęp, s. 7.
} 
pól, pierwszej części debiutanckiej powieści Kobiety. Powieści, w której we wszystkich trzech częściach pojawiły się przetworzenia przeżyć, postaci, aforyzmów i motywów z życia codziennego, przedstawionych w pierwszym tomie Dzienników. Ten autobiografizm jest niezwykle istotny, wpływał bowiem bezpośrednio na kształt utworu oraz na "proces krystalizowania się osobowości”" ${ }^{10}$ pisarki. Przez badaczki ten autobiografizm jest różnorodnie interpretowany. We wstępie do Dzienników Hanna Kirchner napisała o autobiografizmie „przyłapanym na gorącym uczynku” ${ }^{11}$, zaś Grażyna Borkowska we wstępie do powieści Kobiety nazwała go dyskretnym ${ }^{12}$. Na tę wątpliwość częściowo zdaje się odpowiadać sama autorka, pisząc w liście do Zofii Villaume, że w powieści Kobiety, ,jest [...] dużo — prawie wszystko ze mnie, to, co ostatnio przeżyłam" ${ }^{13}$. Wydaje się więc, że obydwie badaczki mają rację. Bowiem sygnały autobiograficzne w powieści z 1906 roku dają się wyraźnie wychwycić. Nie tyle jednak sami je „przyłapujemy na gorącym uczynku”, co autorka chciała, byśmy je zauważyli i cieszyli się radością odkrywcy penetrującego nieznane lądy (gra z odbiorcami? - Nałkowska była znana ze swojego poczucia humoru). Jednocześnie słusznie Borkowska zdefiniowała autobiografizm powieściopisarstwa Nałkowskiej (zwłaszcza w kontekście Kobiet) jako dyskretny. Przyjąć należy, że badaczka, używając tego sformułowania, nie miała na myśli liczby śladów autobiograficznych, lecz formę, w jakiej zostały przedstawione. Proza Nałkowskiej nie ma bowiem znamion narzucającego się ekshibicjonizmu, jaskrawego odkrywania sekretów intymności — śladów autobiograficznych jest wiele, ale są subtelnie, twórczo opracowane. Ta interferencja akcentuje piękno związku literatury i życia.

Kontekst Dzienników jest istotny ze względu na sposób kształtowania przez Nałkowską materiału twórczego, formowania z niego zdarzeń, sytuacji, postaci, opisywania przeżyć. Kirchner we wstępie do Dzienników Zofii Nałkowskiej ${ }^{14}$ tak określiła walory pamiętnikarskiej twórczości autorki:

Wszystko tu dopiero się staje, jeszcze nienazwane, domagające się świadomości, utrwalone in statu nascendi. Oto ten walor dziennika, któremu nie sprosta żadna relacja pamiętnikarska, narzucająca przeżytemu strukturę doświadczenia, wyboru i dystansu ${ }^{15}$.

Nałkowska w Dziennikach dopiero się stawała — jako pisarka, kobieta, odbiorca sztuki. Doskonale to bycie in statu nascendi zostało ukazane także w powieści Kobiety. Wspomniane przekonanie, że literatura to synonim kompletności zaczęło się stopniowo rozmywać i dla samej Nałkowskiej płynne stały się pojęcia „skończoności” — nie

\footnotetext{
${ }^{10}$ H. Kirchner, Wstęp, s. 8.

${ }^{11}$ Tamże.

${ }^{12}$ G. Borkowska, Imperatyw mitości, [w:] Z. Nałkowska, Kobiety, Warszawa 2010, s. 5.

${ }^{13}$ Z. Nałkowska, Dzienniki 1899-1905, s. 349.

${ }^{14}$ H. Kirchner, Wstęp, s. 5-13.

${ }^{15}$ Tamże, s. 6.
} 
tyle samego utworu, stanowiącego pewną zamkniętą całość, ustaloną kompozycję, ale postaci, ich psychiki, codziennych doświadczeń oraz inspirującego charakteru dzieła, które może stać się odniesieniem do dalszej twórczości.

Ponieważ tom pierwszy Dzienników obrazuje proces dojrzewania młodej kobiety — do życia, twórczości, tworzenia więzi międzyludzkich i wykształcania się światopoglądu, stanowi on istotny punkt odniesienia dla niniejszej analizy powieści Kobiety, będąc zapisem dorastania Janki Dernowiczówny (kobiety takiej jak Nałkowska) i pozostałych bohaterek powieści ${ }^{16}$ - do miłości, seksualności, przyjaźni, ergo do życia.

\section{INTELEKTUALNY MIKROKOSMOS NAŁKOWSKIEJ}

Zofia Nałkowska urodziła się 10 listopada 1884 roku w Warszawie. Taka informacja znajduje się w Dziennikach. Kwestia ta nie jest jednak tak oczywista, gdyż istnieje wiele dat informujących o czasie przyjścia na świat pisarki przełomu XIX i XX wieku. Ale nie tylko wielość i rozmaitość informacji w źródłach staje się przeszkodą w określeniu właściwej daty urodzenia autorki. Trudności nastręcza także wrodzone poczucie humoru samej pisarki, która na pytanie o datę urodzenia podobno odpowiedziała: „Moi drodzy, wszystkie są fałszywe”"17.

Pisarka dorastała w domu inteligenckim, „od dziecka otoczona pisaniem”18. Ojciec, Wacław Nałkowski, był pedagogiem, wybitnym uczonym z zakresu geografii, geologii, antropologii, historii ziemi. Jego publikacje przyczyniły się do stworzenia podwalin geografii jako dyscypliny naukowej. Wizerunek ojca, jaki wyłania się ze źródeł pochodzących z przełomu XIX i XX wieku (nie tylko autorstwa Nałkowskiej), to obraz człowieka zawsze skupionego na pracy, pełnego poświęcenia, żyjącego w izolacji, codziennie zmagającego się z wyczerpującą pracą duchową „w chorobie i niedostatku”"19. Zarówno ojciec Nałkowskiej, jak i matka, Anna (z domu Szafranek) poświęcali się pracy naukowej. Anna Nałkowska była autorką monografii i podręczników z zakresu geografii powszechnej, wykładowczynią słynnego „Uniwersytetu Latającego”"20. Cała

\footnotetext{
${ }^{16}$ Tytuł powieści oraz kolejne epizody dzieła Kobiety prezentują wielość miłosnych doświadczeń kilku postaci kobiecych. Jednakże w przekonaniu Kirchner (H. Kirchner, Natkowska..., s. 63) to nie fabuła jest najistotniejsza - wszystkie wydarzenia są bowiem pretekstem do debaty nad sytuacją kobiety. Zagadnienie młodości i dojrzewania kobiety jest tematem niniejszego studium, jednak, ze względu na ograniczone rozmiary publikacji, analiza dotyczyć będzie przede wszystkim postaci Janki Dernowiczówny, zaś kwestię dojrzewania innych bohaterek potraktuje się marginalnie.

${ }^{17}$ Na podstawie: E. Pieńkowska, $d z$. cyt., s. 7. Tę informację podaje także Jan Brudnicki, jednakże w jego opinii, Nałkowska odpowiedziała, że wszystkie daty są prawdziwe (J. Brudnicki, Zofia Nałkowska 1884-1954, Warszawa 1969, s. 11). Kirchner we wspomnianej już biografii Nałkowskiej podała jedynie datę 10 XI 1884 roku jako datę urodzenia pisarki.

${ }^{18} \mathrm{~J}$. Brudnicki, dz. cyt., s. 14.

${ }^{19}$ H. Kirchner, Wstęp, s. 12.

${ }^{20}$ Uniwersytet Latający — tajna instytucja kształcenia wyższego, nazwana tak od ciągle zmienianych lokali w prywatnych mieszkaniach, w których odbywały się zajęcia; działająca w Królestwie Polskim od 1885 do 1905 roku, kiedy to przekształciła się w oficjalnie działające Towarzystwo Kursów Naukowych.
} 
rodzina była zaangażowana w pracę umysłową rodziców ${ }^{21}$ — siostry, Zosia i Hanna pisały pod ojcowskie dyktando (zwłaszcza wtedy, gdy Nałkowski zaczął cierpieć na chorobę oczu), uzupełniały indeksy i spisy ilustracji, pomagały mu w porządkowaniu pracy. Dom Nałkowskich to środowisko, w którym najbardziej cenionymi wartościami były patriotyzm, umiłowanie nauki i postępu oraz szacunek wobec odmienności poglądów, swobody myślenia. Wiele można by napisać o tym, w jaki sposób atmosfera domu rodzinnego wpłynęła na postać Nałkowskiej jako kobiety, myślicielki i pisarki. Fakt, iż dla matki powieściopisarki istotne było wychowanie dzieci w otoczeniu wolnym od restrykcji i więzów konwenansów, nie pozostał bez wpływu na transgresywną osobowość pisarki. Transgresywną, czyli gotową do poszerzania horyzontów - intelektualnych, emocjonalnych, a przede wszystkim płciowych, przekraczania granic płci i płciowości, otwartego mówienia o seksualności i kulturowym obrazie płci, co uwidoczniło się szczególnie w podejmowanych przez główną bohaterkę powieści Kobiety próbach (re)definiowania cech typowych dla danej płci ${ }^{22}$.

Światopogląd autorki ukształtowała także osobowość ojca — od zniechęcenia i odrazy wobec ojcowskiej izolacji w pracy naukowej Nałkowska ewoluowała do podziwu, szacunku wobec poświęcenia, mądrości i codziennego heroizmu rodzica. Warto zwrócić uwagę na to, że zainteresowania badawcze ojca powieściopisarki skupiały się nie tylko na geografii, ale dotyczyły też spraw społecznych i literackich. Wacław Nałkowski, należący do nurtu radykalnej inteligencji polskiej, zaczerpnął kult najlepszych tradycji pozytywistycznych (umiłowanie nauki, walka o demokratyczne swobody, m.in. wolność kobiet i zmniejszenie wpływu kleru na życie świeckie), łącząc te poglądy z postępowymi ideami środowiska socjalistycznego. Nałkowski - monista, determinista, ewolucjonista - wyrażał także swoje opinie o literaturze. Najbardziej znamienną dla poglądów ojca autorki Kobiet jest jego kampania przeciwko tzw. „połaniecczyźnie”, której podstawową konkluzją było przekonanie o upodobaniu Sienkiewicza do filisterstwa i „reakcyjnej zgnilizny” w Rodzinie Połanieckich oraz jego tendencji do apoteozowania „filisterskiej moralności” ${ }^{23}$ w powieści Bez dogmatu. Kwestia ta jest tym bardziej istotna, że poruszane przez Nałkowskiego zagadnienia dotyczyła tzw. „sprawy kobiecej" (problemu praw kobiet), która była szczególnie bliska jego córce, zwłaszcza w pierwszym etapie jej twórczości. Nałkowska dokonała weryfikacji spostrzeżeń ojca, przeprowadzającego analizę z punktu widzenia socjologa i historyka kultury. Pisarka skupiła się na psychologicznych i filozoficznych aspektach problemu.

Światopogląd autorki ukształtowali nie tylko najbliżsi, ale też specyfika środowiska, w jakim żyła pisarka. Do grona osób, które były stałymi gośćmi domu Nałkowskich,

\footnotetext{
${ }^{21}$ Szczegółowo na temat zainteresowań i pracy badawczej rodziny Nałkowskich oraz atmosfery domu rodzinnego wypowiedziała się w biografii pisarki Hanna Kirchner (Nałkowska albo..., s. 12).

${ }^{22}$ Szerzej na ten temat: H. Kirchner, Wstęp. Szkic sangwina, s. 10. Perspektywa gender, niewątpliwie istotna dla kwestii kształtowania się osobowości młodej kobiety, poszukiwania własnego miejsca w świecie, to także kluczowy aspekt w analizowaniu powieści Kobiety w kontekście cech dandysowskich, co stanowi temat do odrębnych rozważań.
}

${ }^{23}$ W. Nałkowski, Sienkiewicziana. Szkice do obrazu, Kraków 1904, s. 5; cyt. za: E. Pieńkowska, dz. cyt., s. 9. 
należeli najwybitniejsi ludzie epoki: począwszy od znanych i powszechnie szanowanych geografów, m.in. Wacława Jezierskiego i Antoniego Sujkowskiego, aż po ludzi pióra, wśród których znalazły się takie wybitne nazwiska jak: Maria Komornicka, Stanisław Brzozowski czy Adolf Dygasiński. Zwyczaj otaczania się najwybitniejszymi myślicielami, twórcami, artystami początku XX wieku pozostał Nałkowskiej także później. Gdy jako młodziutka żona poety Leona Rygiera mieszkała z mężem w Warszawie, ich mieszkanie stało się miejscem wymiany myśli takich ludzi jak: Wacław Berent, Stefan Żeromski czy bożyszcze aspirujących do wielkiego pisarstwa studentów (i nie tylko) Stanisław Przybyszewski.

Dojrzewanie pisarki, która pisanie miała we krwi i która od najmłodszych lat była otaczana wybitnymi umysłami owego czasu, przebiegało w atmosferze intelektualnych rozmów, postępowych propozycji zmian, wybitnych i trudnych pozycji lekturowych. Konieczność (i zdaje się potrzeba) wzrastania w świecie intelektualizmu sprawiła, że Nałkowska już jako 15-letnia dziewczyna czytała dzieła takich autorów jak Henrik Ibsen, Andre Garborg ${ }^{24}$, Emil Zola, Gerhart Hauptmann i inni (warto zauważyć, że młoda Nałkowska dzieła autorów francuskich czytała w oryginale ${ }^{25}$ ). Jan Brudnicki podał, że:

Wśród uwielbianych książek na pierwszym miejscu znajdowały się poezje Tetmajera, dalej utwory belgijskiego dramaturga Maeterlincka i francuskiego poety Verlaine’a. [...] Z wiersza, który bodaj 13-letnia pisarka przysłała swej przyjaciółce widać, że wtedy właśnie tych autorów uznała za swych literackich nauczycieli $[\ldots]^{26}$.

Ponadto ukierunkowane na umiejętność analizy i kształtujące swobodę przekonań (niekoniecznie systematyczne i kompleksowe) wykształcenie, które odebrała Nałkowska na pensji u Anieli Hoene, żony Zenona Przesmyckiego (Miriama) oraz w czasie tajnych prelekcji takich uczonych, jak Jan Władysław Dawid (filozofia i logika), Ignacy Radliński (historia języka francuskiego) czy Cezary Jellenty (historia sztuki), bezpośrednio wpłynęło na kształt twórczości w pierwszym etapie drogi pisarskiej. Wydaje się wręcz, że powieść Kobiety to twórczo przetworzona mozaika z literackich i filozoficznych wpływów autorów czytanych w młodości, swoisty respons na poglądy literackich mistrzów.

Intelektualne znajomości Nałkowskiej, formowanie poglądów na drodze wymiany myśli, umiejętne słuchanie, precyzyjna argumentacja, krytyczne czerpanie z poglądów najwybitniejszych umysłów europejskich — to wszystko ukształtowało nie tylko świat samej poetki, ale i wpłynęło na wybujałość umysłową bohaterek jej dzieł. Dotyczy to

\footnotetext{
${ }^{24}$ Tytuł debiutanckiej powieści to odpowiedź na głośną powieść norweskiego pisarza Andre Garborga Mężczyźni (1886, wyd. pol. 1901). Była to replika istotna w odniesieniu do powieści Nałkowskiej, gdyż obie te powieści odwoływały się do idei płci biologicznej jako pewnego ,rodzaju”. W tym kontekście niewątpliwy, feministyczny wydźwięk powieści Nałkowskiej, w której przedstawiona jest sytuacja kobiety w relacji (intelektualnej, miłosnej, erotycznej) z „Nim” — mężczyzną w ogóle, pozostaje w opozycji do dzieła norweskiego autora.
}

${ }^{25}$ J. Brudnicki, dz. cyt., s. 14; H. Kirchner, Wstęp, s. 10.

${ }^{26} \mathrm{~J}$. Brudnicki, dz. cyt., s. 12-13. 
zwłaszcza powieści Kobiety, w której postaci kobiece odczuwały nieustanną potrzebę analizowania, przetwarzania, wyrabiania sobie poglądów zarówno na drobne wydarzenia dnia codziennego, jak i na tematy egzystencjalne. Główna bohaterka powieści z 1906 roku, Janka Dernowiczówna potrafiła myśleć, analizować każdy drobiazg, wykorzystywać swoją świadomość rzeczy, np. tego, w jaki sposób kobieta działa na mężczyznę, jaki czar potrafi roztoczyć przed $n^{27}{ }^{27}$, jednocześnie będąc gotowa na zadawanie pytań dotyczących zagadnień i spraw ważnych i ostatecznych — relacje międzyludzkie, wolność umysłowa, tożsamość człowieka, śmierć. Wykorzystywała przy tym nie tylko wrodzoną umiejętność analizowania świata i siebie samej, ale też wiedzę pokoleń, zdobycze potęg umysłowych całych wieków kultury europejskiej, mając świadomość tego, co wielcy uczeni mówili, np. o sprawie kobiecej (K, 24). Wyraźny ślad biografii Nałkowskiej w powieści zaobserwować można, zwracając uwagę na relację Dernowiczówny z profesorem Obojańskim, który funkcjonuje w powieści jako Cicero - duchowy przewodnik, pobudzający do intelektualnego rozwoju i duchowych poszukiwań, zachęcający bohaterkę do wykorzystania swego talentu w pracy naukowej (K, 54-55). Postać profesora rodzi skojarzenia z filozofem i literatem Stanisławem Brzozowskim, który wywarł wielki wpływ na Nałkowską, podsuwając wartościowe w jego opinii lektury lub kierując uwagę pisarki na istotne problemy ${ }^{28}$ (podobnie rzecz się będzie miała z relacją między Dernowiczówną a Obojańskim). $\mathrm{Na}$ postać Obojańskiego złożyły się zapewne nie tylko cechy Brzozowskiego. Uczony mógł stanowić literackie uosobienie, swoisty personalny konglomerat wszystkich tych wpływów, z którymi Nałkowska miała styczność w rodzinnym domu, gromadzącym elitę intelektualną kraju.

Wpisana w DNA potrzeba czerpania z dorobku umysłowego i kulturalnego epok, czytania i dyskutowania o tym, co najistotniejsze dla młodej, dojrzewającej kobiety, samodzielnej intelektualnie i życiowo, realizowała się nie tylko w przysłuchiwaniu się wpisanym w codzienność dysputom znajomych i przyjaciół domu Nałkowskich. Młoda pisarka znalazła bowiem osobę, z którą mogła dzielić pasję czytelniczą, potrzebę rozkładania na czynniki pierwsze nurtujących ją problemów. Taką intelektualną towarzyszką stała się już od najmłodszych lat córka znanego orientalisty i historyka filozofii, późniejsza pisarka - Helena Boguszewska. Od dziecinnych zabaw dziewczęta przeszły do dzielenia wspólnych zainteresowań i wspólnych lektur. Przyjaciółki zaczytywały się w dziełach modernistycznych poetów: Kazimierza Przerwy-Tetmajera, Paula Verlaine’a, Maurice’a Maeterlincka. Dzieliły nie tylko fascynacje literackie, ale też lekturowe niechęci - natchnione atmosferą domu Nałkowskich, w którym najbardziej obawiano się wirusa filisterskiej obłudy, nie wyrażały się pozytywnie o niektórych dziełach Henryka Sienkiewicza czy Elizy Orzeszkowej ${ }^{29}$.

\footnotetext{
${ }^{27}$ Z. Nałkowska, Kobiety, Warszawa 2010, s. 26. Dalej skrócona lokalizacja cytatów za tym wydaniem w tekście głównym z podaniem skrótu tytułu $(\mathrm{K})$ i numeru strony.

${ }^{28}$ J. Brudnicki, dz. cyt., s. 18-19.

${ }^{29}$ Tamże, s. 12-13.
} 
Potrzebę znalezienia intelektualnej wspólnoty z drugą osobą (kobieta) Nałkowska przeniosła także na bohaterkę powieści Kobiety, co jest kolejnym, po tendencji do podawania w wątpliwość utartych sądów i poszukiwania własnych dróg w oparciu o lekturowe doświadczenia oraz naukowość środowiska, w jakim wychowywała się Dernowiczówna, sygnałem autobiografizmu powieści. W dziele z 1906 roku główna bohaterka, w której uobecniło się wiele cech pisarki, swoją duchową siostrą uczyniła Martę, doznając rozkoszy myślenia, czytania i rozmawiania z dziewczyną (K, 22-23). Kirchner podała, że powieściowa Marta została wyposażona w pewne cechy postaci rzeczywistej — przyjaciółki pisarki, Zofii Villaume. Martę, podobnie jak Zofię Villaume, cechowało skupienie na filozofii silnego przeżywania i zwielokrotniania swojego cierpienia oraz, przede wszystkim, estetyczna wspólnota z główną bohaterką (Jankę i Martę łączyła podobna relacja intelektualna, jak Nałkowską i Villaume) ${ }^{30}$.

\section{ZGODNA NIEZGODNOŚĆ}

Powieść Nałkowskiej Kobiety to utwór o młodości i dojrzewaniu do życia. Jego bohaterkami były dziewczęta, które dopiero uczyły się siebie, poznawały smak uczuć, zmagały się z problemami, próbowały odpowiedzieć na pytania, jakie stawiała przed nimi codzienność i ich dusza. Pisarka skoncentrowała się na przeżyciach dwudziestokilkuletniej Janki Dernowiczówny, inne kobiety zaś przedstawiła niejako z punktu widzenia głównej postaci, poprzez sytuacje, w których ona się znajdowała.

Kim jest Janka? Wiemy o niej tyle, ile sama o sobie powiedziała. Gdy pojawiały się nowe informacje odnośnie bohaterki, rosła też ilość pytań i wątpliwości. Janka mówiła o sobie, że jest córką murarza, w której nie ma nic prostackiego, dziewczyną pochodzącą z nizin społecznych, samodzielnie zajmującą się mieszkaniem, a przy tym pełną artyzmu, subtelności, z delikatnymi, arystokratycznymi dłońmi i silnie rozwiniętym poczuciem smaku. Była buchalterką, która czytała Przybyszewskiego i wykształconą (gdzie? kiedy?) intelektualistką z zadatkami na uczoną ${ }^{31}$. Bohaterka opisała się tymi słowami:

Pracuję, chociaż nienawidzę pracy, większość część dnia spędzam nad wyjaławiającym umysł sumowaniem nieskończonych kolumn cyfr, a jednak umiem myśleć mądrze, jestem subtelna, wykwintna i chociaż nie piszę poezji, nie śpiewam ani maluję, mam duszę na wskroś artystyczną; żyję prawie w niedostatku, a mam zamiłowania sybaryckie, jak ludzie żyjący kosztem innych $(\mathrm{K}, 68)^{32}$.

Ten opis jest konglomeratem paradoksów, zdawałoby się niemożliwych do pogodzenia spostrzeżeń, które są reprezentatywne dla całej powieści. Janka Dernowiczówna była takim siedliskiem paradoksów — godziła w sobie przekonanie o brutalności życia z witalistycznym, twardym kultem życia i rozkoszy $(K, 18)$, była bezpośrednia i szczera

\footnotetext{
${ }^{30}$ H. Kirchner, Natkowska albo..., s. 63-63.

${ }^{31}$ Tamże, s. 64

${ }^{32}$ Cytat ten stanowi doskonałą syntezę dandysowskiej natury bohaterki, ale, ponieważ dandyzm Janki nie jest tematem przewodnim niniejszych rozważań, jej cechy dandysowskie pojawiają się jedynie w kontekście omawianego zagadnienia dojrzewania bohaterki.
} 
wobec innych, ale kłamała przed sobą (w chwili, gdy słyszała przejeżdżającego Janusza chciała, by ją minął, a jednocześnie była pewna, że odczułaby zawód, gdyby tak się stało — K, 18), jawiła się jako niestandardowa, kapryśna, egotyczna uwodzicielka, która potrafiła się zawstydzić męską śmiałością i oburzyć brakiem zdecydowania, z drugiej strony była tradycjonalistką w postrzeganiu roli mężczyzny w relacji damsko-męskiej — mężczyzna musiał stanowić oparcie, wzbudzać bezgraniczne zaufanie i obronić w trudnej chwili $(K, 30)$. Dernowiczówna chciała być samodzielna, niezależna, a jednocześnie pragnęła mężczyzny rasowego, gotowego otoczyć ją opieką. Wiedziała, że czasami będzie potrzebowała odpocząć w ramionach ukochanego, poczuć się bezpiecznie, choć nigdy się do tego nie przyzna (K, 41). „Jestem zanadto skomplikowana” — mówiła Janka, sama nie potrafiąc określić swojego charakteru, zdefiniować swojego typu $(\mathrm{K}, 68)$.

Te wewnętrzne sprzeczności wyszły na jaw, gdy bohaterka próbowała zdefiniować swoje oczekiwania wobec mężczyzny. Z Rosławskim Janka czuła wspólnotę intelektualną. To, co konstytuowało ich relację to rozmowy o literaturze i miłość do sztuki. Janusz z kolei pobudzał w Jance zmysły — przy nim czuła fale ciepła, jakich nie doświadczała przy Rosławskim (K, 25). Dusza i ciało okazały się w powieści dwiema siłami, które potrzebują dla siebie czegoś zupełnie odmiennego.

Chaos kontrastów, z jakim mamy do czynienia, obserwując przeżycia i doświadczenia Janki, nie powinien wydawać się szczególnie zaskakujący. Po pierwsze, paradoksy ujawnione w przytoczonym cytacie wynikają z cech dandysowskich, jakie nosiła bohaterka. Po drugie, tendencja do wyrażania sprzecznych pragnień lub niechęć do ich werbalizowania w ogóle, np. gdy Janka chciała, by Janusz ją pocałował, ale nie mówiła o tym lub nagłe zmiany nastrojów, sprzeczności odczuwanych emocji (Janka potrafiła łatwo przejść od podniecenia i radości do wstrętu i pogardy $-\mathrm{K}$, 46) zdają się raczej cechą konstytutywną płci pięknej — kapryśność i zmienność od wieków są domeną kobiet. Wreszcie, nieumiejętność dookreślenia swych oczekiwań wynikała przede wszystkim z tego, na jakim etapie znajdowała się bohaterka - to czas dojrzewania, radzenia sobie ze zmianami wokół siebie i w sobie, redefiniowania swojej pozycji w świecie. To po prostu dojrzewanie do życia, charakterystyczne dla każdego młodego człowieka, który dopiero stoi na początku drogi życiowej. Słusznie zauważyła Kirchner, że „»prawdziwy« jest człowiek w całości [wyróżnienie - H. K] swoich najbardziej nawet sprzecznych pierwiastków"33. Ten, który swe człowieczeństwo dookreśla, ma w sobie tych sprzeczności zdecydowanie więcej i wynikają one z dopiero rozpoczętego procesu formowania swej osobowości.

\section{DOJRZEWAJĄCY UMYSE}

W niniejszej części będzie analizowane dojrzewanie bohaterki w kontekście umysłowym, duchowym, egzystencjalnym. Celem jest ukazanie, w jaki sposób okres dorastania kształtował w Jance umiejętność myślenia, samopoznania i rozstrzygania wąt-

\footnotetext{
${ }^{33}$ H. Kirchner, Wstęp. Szkic sangwina, s. 9.
} 
pliwości. Poruszone zostanie także zagadnienie samoświadomości Dernowiczówny, postrzegania samej siebie. Kolejną część stanowić będą rozważania dotyczące dojrzewania Janki do tworzenia relacji międzyludzkich (przyjaźni, miłości) i wiążącego się z tym zagadnieniem rozwoju psychoseksualnego bohaterki. Ponieważ powieść Kobiety, a szczególnie pierwsza część Lodowe pola, stanowiła zapis strumienia świadomości głównej bohaterki, trudno jest niejednokrotnie oddzielić kwestię sprzeczności w samej postaci i w jej stosunku do innych od procesu dojrzewania do funkcjonowania w świecie, czy w podejściu do miłości Janki abstrahować od dojrzewania do seksualności.

Janka to młoda, ucząca się życia kobieta in spe, która nie doświadczyła jeszcze goryczy życiowych doświadczeń. Powieść rozpoczyna się poetyckim i metaforycznym opisem, symbolizującym dziewczęcość głównej bohaterki.

Opasuję się powojami kwitnącymi i wyką, na głowę uplatam wielki, ciężki wieniec z bławatków i kładę się na polanie leśnej twarzą w niebo. [...] Ciepło jest, cicho, ptaki delikatnie, urywanie ćwierkają — prawie szepcą. [...] Zamykam powieki przed słońcem, które przez drżące listki brzozowe sieje po igliwiu niespokojnie rozmigotane cętki $(K, 17)$.

Z opisu tego, subtelnie i nienamacalnie, wyłania się sensualna, nieuświadomiona jeszcze siła kobieca, beztroska i piękno świata młodej dziewczyny, błogość leniwego dnia bez smutków i trosk. Symbolem tej dziewczęcości jest wieniec z bławatków, radosne opasywanie się powojami wyki — kwiaty symbolizują tę rozkwitającą w słońcu młodość. Scena jest z pozoru niefrasobliwa, lekka. W opisie pojawił się jednak, ledwo zauważony, „wielki, ciężki wieniec”. Młoda dziewczyna, marząca i rozbudzająca się niczym otaczające ją kwiaty do życia, plotła wieniec gruby i ciązący jej na głowie. W tym fragmencie mamy już sygnał tego, że życie dziewczyny nie było pozbawione trosk, a ona sama niefrasobliwa czy nieuświadomiona. Jakieś skomplikowane przemyślenia krążyły jej po głowie, chwilowo odsuwane, by nie rozproszyć magii chwili.

Chmura ciemnych myśli nie przysłoniła delikatności i uroku, jakie niósł opis Dernowiczówny jako młodej, rozbudzającej się w doskonałej harmonii z otaczającą naturą, idącej na spotkanie życia, słonecznej i silnej w swej młodości kobiety $(\mathrm{K}, 18)$. Postawienie znaku równości między młodością a poczuciem mocy, potęgi, niekiedy też niefrasobliwości jest wyraźne w chwili, gdy Janka powiedziała: „I doznaję rozkosznego wrażenia nieskończonej jakiejś potęgi. Nie widzę krańca trwania mego i mego panowania. [...] jestem wieczna, nieuśpiona świadomość, jestem wszechświat" (K, 32-33). Kto, jeśli nie młody człowiek u początku drogi życiowej czuje się, jakby miał świat u swych stóp, jakby mógł zrobić wszystko, wszystko osiagnąć. Czuje euforię, rozpierającą moc i umiejętność osiągnięcia każdego celu. Czasami jednak pod niefrasobliwością Janka ukrywała niepokój związany z coraz częściej pojawiającymi się pytaniami o tematy i sprawy transcendentne w swym wymiarze - czy zwierzęta mają duszę (K, 33), co czeka po drugiej stronie, czym jest śmierć, wiara i jaki jest sens egzystencji tu na ziemi (K, 37-41). Te rozmowy wydawały się jednak raczej wywołane fascynacją światem ponadzmysłowym, niepoznawalnym, ciekawością poznawczą cha- 
rakterystyczną dla młodego, inteligentnego, obdarzonego umiejętnością krytycznego myślenia umysłu. Przynajmniej ze strony Janki. Marta bowiem najpierw próbowała przekonać samą siebie do tego, że jedynym jej pragnieniem jest przejście przez życie z „bezgraniczną, spokojną słodyczą” (K, 23), by później stwierdzić, że nienawidzi życia, bo wokół siebie widziała wiele niepotrzebnego, niezrozumiałego zła (K, 50-51). Od tej pory już się nie oszukiwała, przestała twierdzić, że estetyczne i szlachetne życie to jedyne, czego pragnęła. Nie ukrywała już cierpienia, wręcz przeciwnie — zaczęła się lubować w spełnianiu roli kobiety, której przeznaczeniem jest ból.

Strach, który obie kobiety - mniej (Marta) lub bardziej (Janka) — skutecznie próbowały ukryć, dotyczył nie tylko kwestii natury egzystencjalnej, duchowej, intelektualnej, poznawczej, problemów fundamentalnych dla funkcjonowania człowieka jako istoty myślącej, wątpiącej, dążącej do wiedzy, ale też problemów bohaterki jako kobiety - uczuciowych, seksualnych i tożsamościowych. Janka była swobodna w dzień, ale nocą towarzyszyło jej tęskne, tragiczne wręcz przekonanie o tym, iż wraz z odejściem Rosławskiego utraciła szansę na prawdziwe partnerstwo. Cierpienie, związane z utratą pierwszej miłości, wydaje się charakterystyczne dla młodej, nieco nadwrażliwej, przesadnej w okazywaniu emocji, bądź co bądź, nastolatki (chyba każdej kobiecie strata pierwszego ukochanego jawiła się jako życiowa tragedia, po której nie ma już miejsca na nową miłość). Marta także przeżyła ból rozstania. Jej relacja z Witoldem Imszańskim miała trudne początki, gdyż przyjaciółka Dernowiczówny nie mogła pogodzić się z myślą, że nie byłaby pierwszą kobietą Janusza. W tym względzie Marta zdecydowanie bardziej zderzyła się z życiem — jej ideał czystej, szlachetnej miłości do urodziwego Imszańskiego legł w gruzach pod wpływem jego szczerych wyznań na temat zmysłowych doświadczeń z przeszłości ${ }^{34}$. I choć Marta nie była kobietą starą, doświadczenia jej życia były tak liczne i bolesne, że bohaterka widziała już ozłoconą jesień życia, ale nie pamiętała jego wiosny $(\mathrm{K}, 69)$. Tak, jakby cierpienie sprawiło, że ominęła etap dziewczęcego rozkwitania, budzenia się do życia jak kwiaty na wiosnę i przeszła od razu do statecznej dojrzałości wieku średniego.

Na początku powieści niezwykle silne i wyraziste jest witalistyczne ukochanie życia i kult rozkoszy. Mimo wszystko. I to jedno zastrzeżenie, uczynione przez bohaterkę, po raz kolejny ma uświadamiać odbiorcy, że młodość Janki będzie przebiegać ze świadomością, że życie jest brutalne i należy mu się poddać z rezygnacją. Dernowiczówna była już „po dorosłemu” świadoma, że nie ma na wiele rzeczy wpływu. W obliczu tej niemożności bohaterka starała się, by na ,gruzach marzeń mistycznych” (K, 18) wyrósł bujny kwiat życia, a więc tworzyła swoją pozytywną filozofię radości życia i rozwoju mimo wszystko [wyróżnienie - A. K.]. Życie witane „śmiechem dzwoniącym”

\footnotetext{
${ }^{34}$ Zob. G. Zapolska, O czym się nawet myśleć nie chce, Kraków 2004. W powieści główna bohaterka, Marysieńka także uległa obsesji na punkcie poprzednich kobiet męża, który lubował się szczególnie w kobietach z tzw. półświatka. Zarówno w powieści Zapolskiej, jak i w dziele Nałkowskiej „zdradzone” kobiety snuły ekspresjonistyczną w formie historię przeżyć i cierpień, posługując się obrazowaniem pełnym brudu, krwi i ciemności. Takie projekcje wyobraźni obu kobiet odnosiły się do dotychczasowych przygód ukochanych mężczyzn, symbolizując ich plugawość i niszczycielską siłę zdrady.
} 
$(\mathrm{K}, 18)$ to nie beztroskie, pełne szczęścia bytowanie; ten śmiech ma bowiem zagłuszyć cierpienie i znój myślenia o nierozwiązywalnych paradoksach ludzkiego istnienia.

Jak już wspomniano, Janka była młodą kobietą, która dopiero próbowała zdefiniować swoje życia. Jednocześnie jednak bohaterka nie ograniczyła się do ukształtowania swojego świata, sięgała bowiem dalej, próbując odpowiedzieć na pytania o kwestie fundamentalne dla sensu istnienia człowieka. Dernowiczówna ciągle poszukiwała, analizując sytuacje dnia codziennego i swoje reakcje na nie i podając w wątpliwość każdą ideę zbudowaną na niepewnych fundamentach. By poszerzyć swoje horyzonty myślowe, szukała partnerów do równorzędnej dyskusji (Marta, prof. Obojański) i czerpała z osiągnięć myśli ludzkiej utrwalonych w dziełach kultury pisanej. Odczuwała rozkosz myślenia i rozmowy z Martą, lubiła też siadać w gabinecie profesora, rozmawiać z nim i czytać sugerowane przez niego książki. Nie bała się uznać kogoś za swojego mistrza, tym bardziej nie obawiała się wypracować własnej filozofii. Sama twierdziła, że to od Obojańskiego zaczerpnęła cały repertuar pojęć i zjawisk negowanych, zaś pozytywną filozofię stworzyła sobie sama. Nie zaprzeczała przy tym ogromnemu wpływowi, jaki miał na nią uczony. Janka mówiła: „On znacząco przyczynił się do mojego uświadomienia" (K, 54-55). Obojański, mimo swej surowości i krytycyzmu, pozytywnie oceniał postać Dernowiczówny. Tylko Janinę uznał za partnerkę godną dyskusji, ona była w jego opinii wyjątkiem od reguły, że kobiety są pozbawione umiejętności logicznego myślenia $(K, 55)$. Obojański cenił sobie inteligencję pozbawioną konwenansów, nie posługującą się schematami małomiasteczkowego, obłudnego postrzegania. Gdy profesor zarzucił kobietom błędne rozumienie emancypacji jako szansy na uzyskanie czegoś więcej niż równouprawnienie ekonomiczne (kobiety niesłusznie domagały się, według niego, również emancypacji obyczajowej), Janka przyznała mu rację, mówiąc: „[...] ładnie by wtedy świat wyglądał” $(\mathrm{K}, 55)$.

Janka traktowała uczonego z mieszaniną specyficznego szacunku i pobłażliwości, nie ujmując mu inteligencji, lecz traktując z ironią jego namowy, by poświęciła się pracy naukowej. Rozmowy z Obojańskim to dla Dernowiczówny doskonała platforma wymiany myśli, ale też miejsce umysłowych ćwiczeń, podczas których zdobywała kolejne umiejętności: szermierki słownej, rzucania argumentami, opanowania właściwych emocji, giętkości poglądowej.

Dla Janki ta tak ceniona przez Obojańskiego mądrość to nie tyle logika wysnuwania wniosków i ich analiza. Bohaterka definiowała ją jako zdolność wyjścia poza schematy ${ }^{35}$, jako:

rzadką, niespotykaną prawie zdolność rozumienia wszystkiego i niedziwienia się niczemu, zdolność odrzucenia wszystkich uprzedzeń i dogmatów, [...] otrząśnięcia się z ustalonych form myślenia [...], zdolność wychodzenia z siebie i przypatrywania się obiektywnie sobie i wszystkiemu z zewnątrz (K, 55-56).

\footnotetext{
${ }^{35}$ Zauważalny jest tutaj pewien związek bohaterki z Nałkowską, dla której, dzięki atmosferze domu rodzinnego i wychowaniu matki, niezamykanie się w ramy utartych sądów było bardzo istotne. W tę cechę, jak i wiele innych, wyposażyła powieściopisarka Jankę Dernowiczównę.
} 
Trudno chyba o bardziej przemyślaną definicję mądrości, zwłaszcza u dwudziestokilkuletniej dziewczyny. Bohaterka nie tylko wypracowała własną definicję, ale też starała się według niej postępować. Miała otwarty umysł - swobodnie dyskutowała o kontrowersyjnych zagadnieniach z Obojańskim $(\mathrm{K}, 55)$, o roli prostytutek z Wildenhoffową $(K, 109)$, szła na spotkanie z uczciwie już żyjącą byłą kokotą, panią Wieloleską (K, 120-122), decydowała się na poznanie świata dekadentów, w którym narkotyczne wizje i swobodna wymiana zdań to zdarzenia konstytuujące codzienność (K, 212-219).

Ale nie tylko to jest fascynujące w bohaterce Kobiet. Janka z pełną konsekwencją bowiem realizowała także ostatni punkt ze swej definicji mądrości - wyjście poza siebie i przyjrzenie się sobie z zewnątrz. Wówczas samoświadomość Janki budowała się przede wszystkim na świadomości własnej urody. Janka wiedziała, kiedy pięknie wygląda, kiedy roztacza czar i wywołuje zachwyt swoim wejściem do pomieszczenia $(\mathrm{K}, 26)$. Znamienna w tym względzie jest scena tańców na balu. Janka, tańcząc, spoglądała w lustra ${ }^{36}$, dostrzegając swoje piękno, egotycznie je kontemplując. W oczarowaniu samą sobą nie ma nic z przesadnej arogancji, Janka zdawała sobie sprawę, gdzie znajduje się granica dobrego smaku, dbała o to, by każda poza była dopracowana i użyta w odpowiednim momencie. Brak epatowania przekonaniem o swej urodzie nie oznaczał jednak, że ludzie nie zauważali jej narcystycznego zachowania. Janka wyczuwała wrogość innych, jednakże nic sobie z tego nie robiła. Wiedziała, że zachwyca, zdawała sobie sprawę, że nawet ci, którzy jej zazdroszczą, muszą przyznać, że wygląda olśniewająco w swej sukni. Janka zdawała się rzucać wyzwanie otoczeniu — nie tylko jej postawa, śmiałe spojrzenia, pewność siebie świadczyły o świadomości swej urody. Ta pewność ukazana została w passusie, w którym Janka opisała się w czasie tańca:

Tańczyć lubię w równym prawie stopniu, jak jeździć konno. I cudnie tańczę. Raz po raz widzę się w którymś z luster długich do ziemi — jasna w jakichś czarnych ramionach, jakby ociągająca się, leniwie i sennie w tył przegięta, ukazująca zza czerwonych warg białe, mocno zaciśnięte zęby; seledynowa gaza opływa mię luźno, jak woda. Białe wielkie kwiaty nenufarów [wyróżnienie - A. K.] oplątują mię wokoło elastycznymi, niby węże, łodygami (K, 27).

Bohaterka była piękna, bajecznie ubrana, w wystudiowanej pozie, w której z całą świadomością wiedziała, że prezentuje się doskonale, otoczona kwiatami nenufarów. Owe kwiaty były owym wyzwaniem rzuconym innym, zwłaszcza kobietom, bowiem Janina była świadoma sił rządzących światem, znała reguły gry damsko-męskiej, w której toczyła się nieustanna rywalizacja pomiędzy kobietami. Symbolika nenufarów jest niezwykle istotna, kwiaty te bowiem, podobnie jak narcyz, uchodzą w Europie za znak

\footnotetext{
${ }^{36}$ Lustro stanowi przede wszystkim rekwizyt Narcyza (zob. M. Głowiński, Narcyz i jego odbicia [w:] tenże, Mity przebrane, Kraków 1994), jest ono jednak także przedmiotem niezbędnym i niezwykle istotnym dla postaci o cechach dandysowskich. To w lustrze ukazuje się ucieleśnienie piękna — dandys, to lutro pomagało w uświadomieniu sobie własnego piękna, w niewątpliwie narcystycznym (co wskazuje na związek narcyzmu i dandyzmu) studiowaniu wyglądu. Owocem uważnej analizy ma być stworzenie perfekcyjnego wyglądu, wypracowanie odpowiednich gestów i ruchów.
} 
obojętności, egoizmu, także braku serca. Nie należy posądzać bohaterki o potrzebę zasygnalizowania braku serca, z całą pewnością jednak piękno tych egzotycznych kwiatów (obok orchidei, anemonów, irysów, lotosów tak chętnie wykorzystywanych w pisarstwie modernistycznym ze względu na egzotykę, wyjątkowość i bogatą symbolikę ${ }^{37}$ ) w połączeniu z semantycznym odniesieniem do postawy egoistycznej (tu: w znaczeniu egotycznej, narcystycznej) wywoływały wrażenie, o jakie młodej kobiecie chodziło.

Radość, uśmiech, taniec, ruch — to wszystko jest domeną euforycznej, nieposkromionej młodości. To na parkiecie, w czasie tańca bohaterka czuła w sobie wybuch witalistycznej siły, rozpierającej energii, oraz fascynację pędem tańca i świetlistym rozmyciem otoczenia w czasie niekończącego się wirowania (K, 28). Janka doceniała piękno wokół siebie, piękno zewnętrzne miało bowiem dla niej duże znaczenie. Czar chwili nastrajał Jankę tak afirmująco, że z przyjemnością obserwowała "dzikie ognie” (K, 28) w oczach Janusza, oddawała się porywającej sile, z jaką prowadził ją w tańcu, by później, w błogim uspokojeniu, przytulić się do jego kolan. (K, 29).

Rozbuchana siła i energia tańca, ukazane w tanecznej scenie, skontrastowane zostały w powieści z dojrzałą, niekiedy smutną świadomością bohaterki. Ta młoda kobieta, ciesząca się wirem tańca, do którego została porwana przez swawolnego hreczkosieja, sprawiała wrażenie, jakoby przeżyła już wszystko. „Właściwie — doszłam już do samego dna”, mówiła Janka (K, 71). Bohaterka skonstatowała, że skosztowała owoc drzewa świadomości, „że nie ma dobrego i złego” (K, 71). Pewność siebie zachwyconej swą urodą kobiety zmieniła się w rezygnację i wątpienie o wszystkim:

A ja nic nie mam, naprawdę nic nie mam. Jestem za mało piękna, by piękność tę w sobie ukochać. A mądrość jest mądrością tylko z pewnego punktu widzenia — jeśli się ten punkt zgubi, to pojęcie mądrości istnieć przestaje; nie jestem niezwykła — bo za mądra jestem na to, by być sztuczna i tajemnicza. [...] w nic nie wierzę i nic mnie nie obchodzi (K. 71).

Nie ma już tak starannie wypracowanej definicji mądrości, nie ma wiary w urodę, we własną wyjątkowość. Czy dotychczasowe wartości zniknęły na zawsze?

[...] tym zwątpieniem mym i zobojętnieniem dla wszystkiego nie pieszczę się, jak typowi dekadenci - przeciwnie, przed ludźmi i sama przed sobą udaję wesoła, szczęśliwą, piękną, zadowoloną z tego, że to ja właśnie sobą jestem... A i to nie dlatego, bym rozmyślnie ukrywała swą tajemnicę, tylko dlatego, że wesołość moja jest dla mnie mniej nudna od mego zwątpienia (K, 71-72).

Wbrew pozorom wypracowana filozofia wcale nie legła w gruzach. Stała się ona wielowymiarowa, niejednoznaczna (może nawet dla samej bohaterki?). Te zmiany, przeobrażenia, negacje, ta walka wiedzy o bycie i jednoczesnej świadomości niewiedzy $(\mathrm{K}, 81)$ są dowodami na to, jak wielkiego przepracowania dokonuje myśląca jednostka, dojrzewająca intelektualnie i duchowo. Najwięcej przemyśleń, prób ukonstytu-

\footnotetext{
${ }_{37}$ Zob. I. Sikora, Przyroda i wyobraźnia: o symbolice roślinnej w poezji Młodej Polski, Wrocław 1992 i Mtodopolska florystyka poetycka, Wałbrzych 2007. Autor poświęcił te prace analizie symboliki kwiatów popularnych w prozie i poezji modernistycznej.
} 
owania swego bytu głównej bohaterki pojawiło się w części zatytułowanej Lodowe pola. Szczególnie ostatnie akapity tej części stały się obrazem walki antagonistycznych sił w bohaterce, walki o samookreślenie:

Wiem to, czego nie wie nikt: że nie potrzebuję jej [zagadki bytu — dop. A. K.] wiedzieć na to, by wiedzieć wszystko. Nie ma mnie. Jestem w świecie, który jest negacją tego świata - ale taką negacją, w której nie ma rozróżnienia negacji i afirmacji $(\mathrm{K}, 82)$.

W części II Janka mówiła już jak kobieta, która wiele przeszła, a jedyne, co jej pozostało, to „mądrość uśmiechu w samotności” i „duma świadomości, że to ja właśnie jestem sobą" $(K, 84)$. Nastąpiła zmiana perspektywy — Janka już nie udawała zadowolenia z tego, kim jest, lecz wydawała się mieć na tyle stabilny ogląd, że odczuwała dumę z bycia sobą. Wydaje się, że wątpliwości już zniknęły, a zastąpiła je smutna pewność - pozbawienie złudzeń, np. co do wierności mężczyzn $(K, 86)$, przekonanie o jałowości życia $(K, 128)$. Z drugiej strony jednak Janka nadal twierdziła, może już z mniejszą mocą, ale nadal wyrażała przekonanie: ,ja nic nie wiem i zazdroszczę im pełnych ustalonych poglądów” (K, 116) i ponownie w trzeciej części: ,ja sama nic nie wiem" (K, 158).

Być może więc Janka stanęła na pograniczu dwóch światów, młodości i dorosłości, i znajdowała się po trosze w każdym z nich? Być może to tylko kobieca nadwrażliwość i modernistyczna egzaltacja kazały jej roztrząsać każde wydarzenie i podawać w wątpliwość to, co ledwo zbudowane? Być może wreszcie bohaterce pisane jest „nie wiedzieć", nieustannie negować i wątpić, by cały czas się doskonalić i udowodnić, że granice między wiedzą a niewiedzą, młodością a dorosłością, autobiografizmem a literackością są płynne, a same zjawiska silnie interferencyjne? I nie chodziło bynajmniej o pokazanie, że nic nie jest pewne, lecz o to, że czasami nie sposób postawić linii demarkacyjnej, a proces intelektualnego dojrzewania nigdy nie jest skończony. Doskonałe podsumowanie i wyjaśnienie wątpliwości dotyczących niejednoznaczności dojrzewającej kobiety, ciągle zmiennej filozofii i nieustalonego jeszcze obrazu własnego ,ja” dała Ewa Pieńkowska. Badaczka tłumaczyła, że mieszanina szalonej ambicji i niepewności, ekscytacji i rozpaczy, wiary i całkowitego zwątpienia, egzaltacji i zdolności do racjonalizacji wynikają z tego, na jakim etapie znajduje się kobieta w wieku dorastania. Pieńkowska owo wyjaśnienie stosuje do postaci Nałkowskiej oraz doświadczeń rozpisanych w Dziennikach 1899-1905, z pewnością można je jednak rozszerzyć także na bohaterkę analizowanej powieści. Zarówno dziennik, jak i powieść z 1906 roku mogą zostać nazwane „kroniką gorączkowych poszukiwań formuły osobowości własnej, modelu, który z podsuniętych przez epokę konwencji tworzyłby jakość indywidualną i odrębną" ${ }^{38}$. I te gorączkowe poszukiwania, próbowanie „po omacku” różnych modeli stanowią wyjaśnienie ciągłej niemożności określenia, po jakiej stronie stała bohaterka - pełnej samoświadomości czy ciągłych wątpliwości.

\footnotetext{
${ }^{38}$ E. Pieńkowska, dz. cyt., s. 8.
} 
Relatywna jest nie tylko granica między stabilną filozofią a nieustalonymi poglądami. W powieści kwestią trudną do rozstrzygnięcia jest także wiek głównej bohaterki. Osoby starsze od niej uważały ją za młodą, jeszcze niedotkniętą cierpieniem. Profesor Obojański stwierdził, że Janka jest „prawie dzieckiem jeszcze” (K, 63), Wildenhoffowa była przekonana o tym, że Dernowiczówna jest za młoda, by zetknąć się z trucizną świata $(K, 126)$. Rosławski zdawał się traktować Jankę jako nieco bardziej dorosłą, stwierdził, że przez wakacje Janka zmieniła się, urosła, bo w zeszłym roku miała w sobie wiele z pensjonarki $(\mathrm{K}, 65)$. Mężczyzna nie uważał jej jednak za dorosłą, lecz za młodą kobietę, która urosła o parę centymetrów i zmieniła się trochę na twarzy (nieznana jest przyczyna rozstania Rosławskiego z Janką, można jedynie przypuszczać, że dla mężczyzny podlotek nie był odpowiednią kandydatką na kobietę i towarzyszkę rozmów i dlatego miłość bohaterki pozostała nieodwzajemniona).

Sama Janka uważała się z kolei za dorosłą, doświadczoną, uświadomioną w trudach życia kobietę. Nierwiską, koleżankę z pracy, z którą rozmawiała o relacjach damskomęskich, przekonywała, że jest stara, więc można się jej zwierzyć (K, 58). Rozstanie z Rosławskim wydawało się odległe (K, 135). Z drugiej strony, Janka wypowiedziała jedno zdanie afirmujące własną młodość: „Tak krótko żyłam — a tyle pięknych mam wspomnień, jak kwiaty" (K, 135). Stwierdzenie to poprzedzone zostało radosnymi okrzykami, witającymi wiosnę. I w tej wiosennej aurze nastąpiło rozbudzenie młodości Janki, jej euforyczna afirmacja wiosny, świata, piękna i swojego młodego wieku.

Rozważania dotyczące intelektualnego dojrzewania bohaterki warto zamknąć cytatem obrazującym sytuację Janki na początku drogi życiowej:

Leżąc, śpiewam półgłosem, jednostajnie. Żadna melodia znana, tylko kompilacja z różnych słyszanych i niesłyszanych pieśni. Tak samo słowa: przypominam je sobie lub układam na poczekaniu $(\mathrm{K}, 17)$.

Układana przez Jankę melodia (życie?) nie była jeszcze znana, jawiła się raczej jako połączenie melodii słyszanych (doświadczenia innych ludzi, lekturowych bohaterów?) oraz melodii niesłyszanych — oczekiwań, marzeń, planów, domysłów. Janka wypowiedziała odwieczną prawdę, prawdopodobnie nawet sobie tego nie uświadamiając, że każde życie ludzkie to mieszanina odwołań do doświadczeń pokoleń przodków, osiągnięć wieków kultury i myśli ludzkiej, a więc powtarzalnych szablonów oraz pragnień, które modyfikują te schematy, czyniąc każde życie indywidualnym doświadczeniem.

\section{CiaŁo, uczucia}

Dojrzewanie bohaterki to nie tylko samopoznanie intelektualne, to także wątpliwości i poszukiwania uczuciowe i seksualne. Ludzka osobowość nie kształtuje się w odosobnieniu. Do jej pełnego rozwoju potrzebne są kontakty z innymi ludźmi, nawiązywanie z nimi relacji emocjonalnych, uczuciowych, stopniowo także seksualnych. Okres dojrzewania to bardzo istotny moment dla późniejszego funkcjonowania człowieka w świecie — kształtuje się wówczas zdolność do nawiązywania intymnych (nie tylko w sensie cielesnym) relacji z ludźmi, angażowania się w życie innych. To 
czas, kiedy człowiek uczy się tego, jak zaufać drugiej osobie, jak pójść na kompromis, jak radzić sobie z problemami swoimi i innych.

Okres dorastania to czas poszukiwań osób, które mają takie same zainteresowania, z którymi znajdzie się tzw. wspólny język, które wspierają w trudnych chwilach i cieszą się naszymi sukcesami. Pragnieniem Janki nie było jednak zdobycie przyjaciela „na dobre i złe”. Bohaterka wybierała z otoczenia tych ludzi, którzy odpowiadali jej potrzebom, spełniali określone rolę, w inny sposób ją zajmowali.

Dobrą towarzyszką dla Janki wydawała się Marta. Zwłaszcza w pierwszej części powieści obie kobiety były sobie bliskie. Znają się, rozumieją się doskonale, przyjemność sprawia im wspólne spędzanie czasu na dzieleniu się wrażeniami z przeczytanych książek i rozmowie o sprawach ważnych w ich życiu. Okazało się jednak, że relacja między nimi, jak wszystko w życiu Janki, była niestandardowa — obie bowiem, mimo iż ceniły sobie swoje towarzystwo, doskonale zdawały sobie sprawę, że między kobietami nie jest możliwa szczera miłość (K, 22-23). Postaci z powieści Kobiety pogodziły się z tym, że obiektywizm nie jest możliwy, pełna uczciwość w relacji jednej kobiety z drugą nie istnieje. Kolejną immamentną cechą przyjaźni jest to, że na przyjaciółkę zawsze można liczyć. Ona jako jedyna nie ocenia, wysłucha i nie będzie bagatelizować problemów bliskiej osoby. Janka zachowywała się zupełnie inaczej w stosunku do przyjaciółki - często wydawała się znudzona opowieściami nieszczęśliwej Marty, uważała je za „banalne i głupie troski zdradzanej żony” (K, 99).

Wreszcie, najistotniejszą cechą przyjacielskiej relacji między ludźmi jest pewność, że druga osoba nigdy nie zdradzi. Janka zadała swojej przyjaciółce ogromny cios, uwikławszy się w romans z jej mężem, Imszańskim. Dla Janki zdawały się nie mieć znaczenia żadne kategorie moralne, nie odczuwała ona solidarności z inną kobietą (z kobietą notabene jej bliska), nie wydawało się jej, by kolejna kochanka Witolda stanowiła dla Marty jakąś różnicę. Janka nie rozumiała, że tu nie chodzi o „jaką̧s" kobietę i przez to zdrada boli bardziej, bo dotyczy najbliższej osoby.

Przyjaciółką nazywała Janka Ginę. Kobiety połączyło odkrycie romansu Imszańskiego z aktorką teatralną. Gina była świadkiem egzaltowanej reakcji Dernowiczówny i swawolnego flirtu z nieznajomym. Gina znajdowała się w podobnej sytuacji co Janka - także cierpiała z powodu zawiedzionego uczucia. Ta wspólnota sytuacji sprawiła, że główna bohaterka nazwała Ginę swoją przyjaciółką, zwierzyła się jej, opowiedziała swoją historię „od początku do końca” (K, 175). To nawiązanie intymnej relacji z drugą kobietą miało raczej charakter epizodyczny, owszem, wywołało je podobieństwo miłosnych doświadczeń, ale chyba największe znaczenie miał fakt, że Gina znajdowała się w tym miejscu, w tym czasie, kiedy Janka odkryła niewierność Witolda.

Wydaje się więc, że Janka nie była w stanie z żadną kobietą nawiązać pełnej, naturalnej, kobiecej relacji. Zawsze grała, korzystała z repertuaru wystudiowanych póz, unikała szczerości. Sama twierdziła, że naturalna jest u niej właśnie ta sztuczność (K, 42). A ponieważ Janka nie zachowywała się w tradycyjny sposób, może właśnie relacje niepodbudowane szczerością i zaufaniem były dla niej naturalne? Wydaje się 
więc, że prawdziwy nie jest związek, w którym nie ma pełnego zaufania, ciągle trzeba coś udawać i przede wszystkim nie ma pewnej moralnej granicy wytyczającej to, czego przyjaciółce zrobić nie wolno. Bardzo istotna jest tutaj perspektywa dandysowska - Janka-dandyska, wyuczona gestów, słów i myśli, przygotowana do odpowiednich reakcji, żyjąca niejako poza prawem moralnym i zasadami, które, jako dojrzewająca kobieta, dopiero do siebie "dopasowuje” (jak dandys kompletuje garderobę), nie potrafiła nawiązać i utrzymać relacji, w której imperatywem mogłyby być wierność, szczerość, moralność.

Janka zdecydowanie lepiej czuła się w otoczeniu ludzi, z którymi łączyły ją nie uczucia, zasady, więzy narzuconych jej (a nie przez nią wybranych) zachowań. Janka odnajdywała się w relacji, w której tym, co łączy z drugą osobą, jest intelekt, rozmowy niekrępujące swobody myślenia. Takimi przyjaciółmi byli dla Janki Stefan Strwiążewski i profesor Obojański. Ten ostatni był jej intelektualnym przewodnikiem, nakłaniającym do poszukiwań swojej drogi. Stefan z kolei wydawał się Jankę zwyczajnie bawić, bohaterka spotykała się z nim wtedy, gdy odczuwała nudę. Obcowanie z tym mężczyzną to dla bohaterki frapujący sposób na poszerzanie horyzontów, na poznawanie niestandardowych poglądów (Stefana fascynowały kobiety z niższych warstw społecznych - pierwotne, niewychowane, nieskażone myśleniem). Pojawia się jednak wątpliwość, czy możliwa jest czysta przyjaźń między kobietą a mężczyzną. Janka stwierdziła: „Chciałabym, by mię pokochał Stefan” (K, 91), mężczyzna pod koniec powieści poprosił Jankę o rękę, wyznał jej miłość $(K, 190)$. Bohaterka nie zdecydowała się jednak na związek ze Strwiążewskim. Zdawała się wówczas pamiętać wypowiedziane przez przyjaciela zdanie, że „przyjaźń jest [...] darem dużo rzadszym i cenniejszym niż miłośc” (K, 87). Przyjaciel nie jest kobietą, nie jest mężczyzną, to „ktoś trzeci” — androgyniczna istota, której nie można przypisywać męskich lub żeńskich cech i której nie można traktować w kontekście jej płci. I choć wydawałoby się, że swego rodzaju intelektualna odwaga, oryginalność doskonale spajałyby tych dwoje, to jednak Janka nie zaryzykowała, porzucając przyjaźń dla czegoś w jej opinii tak niepewnego jak miłość.

Czas dojrzewania to etap, w którym zmieniające się ciało, rosnąca potrzeba bliskości i czułości, instynkt poszukiwania kogoś, z kim będzie można nawiązać nić porozumienia, wreszcie oczekiwania społeczne sprawiają, że człowiek przygotowuje się do stworzenia intymnej relacji z drugą osobą.

Zmiany biologiczne i fizyczne stwarzają warunki do rozwoju seksualności. Cielesne rozbudzenie, otwartość na seksualność drugiego człowieka doskonale opisywały początkowe fragmenty powieści: „[...] śpiewam o jakimś marzeniu sennym, o miłości gorącej, wreszcie przyzywam śpiewem leśnego fauna, bo mam na niego ochotę" $(K, 17)$ oraz „a ja jestem nimfa leśna i czekam fauna” (K, 18). Janka marzyła o gorącym, płomiennym uczuciu, pragnęła, by znalazł się przy niej mężczyzna idealnie do niej pasujący, jak faun do leśnej nimfy. Bohaterka rozbudziła się, pojawił się jeszcze nie do końca wyraźny sygnał zmysłowych potrzeb. Symbolem tej rodzącej się świado- 
mości cielesnej, seksualnej jest płomienna czerwień: „widzę wielką, świetlną plamę, później majaczenia siedmiu barw, później czerwone płomienie” (K, 17).

W kobiecie budziła się cielesność. Obok refleksyjnej duchowości pojawiło się jeszcze nienazwane pragnienie życia - czerwonego, wyrazistego, żywiołowego:

Depcę duszę moją — krwiożerczą, nienasyconą, chmurną duszę, która zabiła mi szczęście. Chcę zerwać dzisiaj czerwony, płomienny kwiat życia. Śpiewem przyzywam fauna $(\mathrm{K}, 18)$.

W tym fragmencie po raz pierwszy Janka tak manifestacyjnie okazała pragnienie nawiązania zmysłowej relacji, oderwania się na chwilę od spraw ducha, tu po raz pierwszy pojawił się ten „imperatyw miłości” — potrzeba kochania, zerwania kwiatu życia (nawiązanie do metaforyki zerwania kwiatu jako utraty dziewictwa). Janka w swoim manifeście miłości nieustannie przyzywała fauna. Nie bez powodu. Faun w mitologii rzymskiej był czczony jako bóstwo lasów i pól, opiekun pasterzy darzący ich stada płodnością. Faun miał zapewnić kobietom płodnośćc ${ }^{39}$. Janka pragnęła fauna, bo jawił się jej jako symbol płodności, życia, złączenia dwojga ludzi w akcie prokreacyjnym. Ponadto faun, jako postać mitologiczna, jest istotą nadnaturalną, nieistniejącą. Janka pragnęła mężczyzny idealnego, jeszcze nie do końca wyobrażonego i nieziemskiego. Faun to także oczyszczenie, wędrówka ku oświeceniu, a przede wszystkim wyzwolenie i sztuka wyboru. Bohaterka powieści odczuwała pragnienie miłości nie pętającej jej więzami ograniczeń — tutaj właśnie objawił się jej bunt wobec zastanych konwenansów, swoboda myślenia, pragnienie wolności - zarówno w sensie zmysłowym, jak i intelektualnym.

Janka na kartach powieści stopniowo odkrywała swoją fascynację seksualnością. Ten zachwyt objawił się w czasie swobodnych rozmów o istotach z demi-monde — kurtyzanach sprzedających swoją miłość i paradoksalnie cieszących się większą swobodą niż tzw. porządne kobiety. To także otwarte mówienie o swoim pożądaniu, pobudzeniu, w którym nie było nic z wulgarności:

Wiosna idzie - Jezus Maria! Wiosna idzie! Słońce piecze — i wieje chłodny wiatr. Jestem taka szczęśliwa i rozszalała jak zwierzę. Rzuciłabym się na szyję pierwszemu ładnemu mężczyźnie napotkanemu na ulicy (K, 134-135).

Fascynacja światem zmysłów to przede wszystkim ciekawość ciała ludzkiego — zarówno męskiego, jak i kobiecego. Szczególnie piękne wydawało się Jance ciało Marty: „Lubię patrzeć na nią, gdy jest rozebrana” (K, 31). W tym zapatrzeniu nie ma nic homoseksualnego, Janka po prostu kochała piękno i potrafiła je dostrzec w każdym szczególe i w każdym człowieku. Nie oceniała bowiem ciała mężczyzny czy kobiety, obserwowała i zachwycała się ciałem w ogóle ${ }^{40}$. Fascynujące wydawało się bohaterce

\footnotetext{
${ }^{39}$ Faun [hasło online], dostęp: 25.06.2014. Dostępny: <http://portalwiedzy.onet.pl/70760,,,,faun,haslo. html>.

${ }^{40}$ Jest to cecha typowo dandysowska.
} 
powieści także ciało Janusza. Mężczyzna zrobił na niej wrażenie silnego, rasowego zwierzęcia $(K, 21)$. Janina chciała go zamknąć w złotej klatce, by mieć go tylko dla siebie. Brat Marty wywołał w niej pragnienie posiadania, obudził w niej zwierzęce instynkty walki o samca, który odpowiada jej potrzebom $(\mathrm{K}, 34)$. Tym samcem, groźnym wilkiem był Janusz, który, nawet gdy wydawał się łagodny i oswojony, roztaczał wokół siebie aurę wrogiej, nieposkromionej siły. Tym bardziej zadowolona była Janka, gdy Janusz zmienił się w potulną owieczkę, która słuchała jej rozkazów, była na jej zawołanie, robiła to, co kobieta chciała. Ujawniła się tu kapryśność Janki i jej kobieca próżność — lubiła, gdy mężczyzna na pozór silny, kładł się u jej stóp i był jej posłuszny. Dlatego z całą świadomością wrażenia, jakie na nim robiła, kokietowała go, zachęcała po to, by później odrzucić. Jako kobieta świadoma „próbowała” mężczyzn, sprawdzała, jaka ich reakcja najbardziej się jej spodoba (scena z pocałowaniem ręki - K, 21). Nawet jeśli pozwalała mu na zmniejszenie dystansu, np. w chwili pocałunku $(\mathrm{K}, 31)$, nadal grała swobodną, niezaangażowaną, nadal nie dawała mu pewności. To niespełnienie często odzywało się w niej wzmożonym pragnieniem doznania ze strony Janusza czułości - pragnęla, by ją pocałował, objął, zachował się zdecydowanie, po męsku (K, 29, 30). Przy nim jej ciało silnie reagowało — odczuwała przy nim ciepło, a twarz płonęła rumieńcem ani wstydu, ani oburzenia, gdy ten przytulał głowę do jej kolan (K, 22). Mimo że w relacji Janki i Janusza to „instynkt” jest siłą warunkującą zachowanie, Janka nie poddała mu się w pełni. W jej starannie zaplanowanej grze do głosu doszły także inteligencja i spryt. Janka kokietowała mężczyznę swoją kobiecą stroną — ale nie ciałem, lecz pięknem inteligentnego umysłu. Czuła, że to właśnie umysł na usługach jej kobiecości tak fascynuje w niej Janusza.

W kierunku Janusza podążał instynkt Janki, jej umysł zaś kierował swe pragnienia ku Rosławskiemu. Janka była zafascynowana umysłowością Rosławskiego i to się nie zmieniło, mimo że o miłości do niego mówiła w czasie przeszłym. Nie wyjaśniła tego, dlaczego się rozstali, wspomniała jedynie, że to była miłość, w której znaczącym elementem była rozmowa o literaturze i wspólna pasja - miłość do sztuki. To była miłość umysłów - Janka nie czuła przy Rosławskim żadnego cielesnego poruszenia (zdawała sobie sprawę, że nie potrafiłaby całować jego zaciśniętych ust, obawiała się jego zimnego spojrzenia), a jednocześnie była nim obsesyjnie zafascynowana, czuła się przez niego przyciągana i wydawało się jej, że tylko on mógłby zostać jej mężem. Janka zdefiniowała małżeństwo jako komunię dusz dzielących wspólne zainteresowania, połączenie tych samych umysłów. Byłaby gotowa zostać żoną tego człowieka, ponieważ „to jest ta jedyna siła, która byłaby w stanie ujarzmić moją [siłę - dop. A. K.]” (K, 74). Rosławski wydawał się jej nie mężczyzną, ale siłą magnetyzującą. On jeden mógłby odebrać jej zwykłą pewność siebie, zmącić jej spokój ducha. I właśnie dlatego, choć czuła, że on był jedynym mężczyzną, z którym mogłaby dzielić życie, udawała przed nim (by nie wyjść z roli — niedostępnej, zimnej, niepoddającej się uczuciom kobiety — K, 119), że zdecydowałaby się na małżeństwo jedynie z rozsądku. Janka, oszołomiona magnetyczną siłą intelektu Rosławskiego, nie wspomniała ani razu o je- 
go urodzie - ten mężczyzna to nie ciało, lecz osobowość. To swoiste ucieleśnienie siły, wobec której maleją moce kobiece. Janka omdlewała nie przez jego olśniewającą urodę, lecz była całkowicie oddana władzy jego umysłu. Uczucia, jakie wywoływał w niej Rosławski, doskonale oddaje metafora tytułowych „lodowych pól” — Janka wyobrażała sobie, że idzie przez lodowe pola i kładzie się u stóp mężczyzny. Mimo iż wiedziała, że przy nim doświadczy tylko zimna i strachu (K, 78), była gotowa poddać się sile, którą reprezentował Rosławski. To nie ból i chłód, symbolizowane przez pusty, czarny staw i wspomniane już otoczenie lodowych pól, mogłyby ją skłonić do zapomnienia o nim. Jedyne, czego bała się Janka, to to, że jego siła przewyższy jej i że utraci swoją dumę (coś, na czym niezwykle jej zależało). Dlatego ostatecznie Janka nie zdecydowała się podejść do czarnego stawu, który oznaczałby zatracenie w pustce, oddanie chłodowi fascynującego umysłu Rosławskiego, jego demonicznej sile. W ten sposób chciałaby udowodnić, że nie jest zwykłą kobietą, podejmującą decyzje spontanicznie, zgodnie z poruszeniami swego serca, lecz posługuje się rozumem, który nie pozwoli jej oddać się mężczyźnie zimnemu jak Rosławski i tym samym zapomnieć o „płomieniach” — potrzebach ciała.

Ciała, które, jak już wspomniano, wywoływało jej ogromną ciekawość. Z przyjemnością obserwowała Imszańskiego w czasie ich pierwszego spotkania (K, 43). Ponieważ Janka lubiła to, co piękne, artystyczne, dystyngowane, jej uwagę zwrócił Witold. Mężczyzna oceniany był przez nią nie tylko z punktu widzenia urody. Janka próbowała wniknać w to, co kryły spojrzenie, uśmiech i gest nowo poznanego człowieka:

Przede wszystkim jest to bezsprzecznie najładniejszy z ludzi, jakich znam. Z nacechowanych jakimś miękkim znużeniem ruchów jego smukłej postaci bije rasa, w jasnych oczach widać bezustanne skupienie myśli i spokojny zapomniany prawie smutek. Posiada wszystkie zalety towarzyskie, mówi zajmująco, ładnie $[\ldots](\mathrm{K}, 43)$.

Mimo zauważalnego zainteresowania jego postacią, Janka traktowała go tylko jako olśniewające zjawisko, element dopełniający piękno otoczenia, nie jak mężczyznę, z którym mogłaby się związać:

Jestem prawie oczarowana, nie spuszczam zeń oczu — i konstatuję jednocześnie, że ten cudny człowiek nie zdołałby nigdy wzbudzić we mnie miłości. Fizycznie jest mi bardziej jeszcze obojętny niż Rosławski. Przyczyną tego jest, jak sądzę, właśnie jego niesłychana uroda, która odciąga odeń uwagę, jako mężczyzny i człowieka. $Z$ równą rozkoszą patrzyłabym na jego portret $(K, 43)$.

Dla Janki równie ważne prócz tego, by wygląd mężczyzny spełniał jej potrzeby piękna, było to, by wywoływał w niej emocje jako człowiek — istota z pragnieniami, odczuciami, poglądami i fascynacjami.

Stosunek Dernowiczówny do Imszańskiego zmienił się po jakimś czasie. Wydaje się, że ta relacja była im pisana, że rzucenie się sobie w ramiona było rzeczą, która prędzej czy później musiała się wydarzyć. Dlaczego? Tego zdawała się nie rozumieć nawet Janka: „Opuściłam głowę na kolana, oczy zakrywając rękami. I nagle opętał mię 
szalony, obłąkany niepokój oczekiwania [...]” (K, 140). Niewystarczalność dotychczasowych relacji i doświadczeń sprawiła, że Janka czekała wreszcie na miłość, w której odnalazłaby siebie. Opuszczenie ramion, stopniowe rozluźnienie ciała sugerowałyby, że Janka przestała grać kobietę, która uczuć nie potrzebuje. Ku Imszańskiemu pociągnęła Jankę niewytłumaczalna i niedefiniowalna potrzeba, już nie instynktu, intelektu, duszy, lecz potrzeba miłości.

I choć ta relacja miała wymiar moralnie niewłaściwy (Janka zaczynała spotykać się z mężem przyjaciółki), kobieta nie myślała o sytuacji rodzinnej Witolda, o tym, jak bliska była jej Marta, nie dopuszczała myśli, że rozbija rodzinę kobiety, która, tak samo jak ona, pragnęła miłości. Ponadto Janka nie brała pod uwagę, że mężczyzna, który zdradzał swoją żonę od dawna, może potraktować relację z nią tak samo jak te dotychczasowe - płytko i swobodnie. Janka zachowywała się jak kobieta, której miłość odebrała zdolność trzeźwej oceny sytuacji. Kobieta wydawała się pewna tego, że dla niej Imszański zmieni tryb życia (Janka pragnęła jedynie, by Witold rzucił swoje kochanki i obiecał jej wyłączność, nigdy w jej rozmyślaniach nie pojawia się postać Marty, Janka nie namawiała mężczyzny do rozwodu z przyjaciółka). Witold jednak nie udzielił jej oczekiwanej odpowiedzi. Janka zaczęła rozumieć, że także i ta miłość nie da jej upragnionej stabilności, ten związek nie oznacza życia w pełnym porozumieniu z mężczyzną, którego darzy uczuciem:

Dzielą nas spojrzenia i łączą pocałunki. A ja szamocę się w tej miłości, jak wzbity nad obłoki latawiec szamoce się na nitce, trzymanej w palcach przez rozbawione pacholę $(K, 157)$.

Janka pragnęła związku, w którym kochanków łączyć będzie wszystko — spojrzenia, gesty, pocałunki, słowa, myśli. Imszański zdecydowanie częściej zamykał jej usta pocałunkiem, pieścił czułymi gestami niż próbował odnaleźć z nią wspólny język myśli. Jego pieszczoty były zachłanne, Janka czuła, jakby te pocałunki wysysały z niej krew (K, 162). Picie krwi (cechę wampiryczną ma kolejny mężczyzna Janki, wystarczy przypomnieć demoniczną, magnetyczną siłę, z jaką przyciągał ją ku sobie Rosławski) jest tutaj metaforą nie tylko słabnięcia w miłosnym upojeniu. To także odzwierciedlenie stanu, do jakiego Witold chciał doprowadzić kobietę — pragnął, by była coraz bardziej podatna, by przełamywała mu się w rękach ,jak więdnący w żarze słońca kwiat" (K, 162; ponownie wywołana symbolika kwiatu sugerowałaby, że Imszański „czyhał” na dziewictwo Janki).

Mężczyzna chciał zawładnąć Janką. Wydaje się, że tak jak dla Marty życie z nim było mieszaniną bólu i rozkoszy, tak i Janka znajdowała się na początku drogi, gdzie Eros i Tanatos łączą się w jedno:

Przywarł do mej szyi, wgryzł mi się w ciało strasznie bolesnym i rozkosznym do obłąkania pocałowaniem. [...] I uczułam na wargach przesłodką czarę jego ust o smaku róż więdnących... I piłam szkarłatne wino jego pocałunków, mocne jak śmierć. Upoiło mię wino szkarłatne... Konam... Może więc dziś $(K, 167)$. 
Wir miłości i namiętności groził całkowitym zatraceniem. Janka pokochała, ale ponownie poniosła klęskę — oddała uczucie mężczyźnie, który był uosobieniem niszczycielskiej siły, zadającej ból wielu kobietom. Dopóki jednak Janka żywiła przekonanie o miłości Witolda, poddawała się tej sile, powoli się zatracała. Gdy jednak uświadomiła sobie, że Imszański nigdy nie kochał jej całkowicie i prawdziwie, uwolniła się od niego, odeszła. Przestała go kochać wtedy, gdy zdała sobie sprawę, że nie dostała jedynej rzeczy, jakiej oczekiwała - miłości $(K, 204)$.

W tym miejscu warto jeszcze zwrócić uwagę na kwestię inicjacji seksualnej Janki. Kobieta nie zdecydowała się na zbliżenie z żadnym z trzech mężczyzn, z którymi była w bliższej relacji. Wydaje się, że najbardziej intymny był jej związek z Imszańskim — ich spotkania były pełne zmysłowych uniesień, pieszczot i gorących pocałunków. Janka zatracała się pod wpływem dotyku Witolda. Zawsze jednak w pewnym momencie Dernowiczówna odzyskiwała spokój i odtrącała mężczyznę, nie pozwalając mu na więcej:

[...] zawsze do pewnej granicy, której nie wykreśla moja wola, tylko sam instynkt. Jest chwila, w której wstępuje we mnie nagle jakaś zimna, ironicznie uśmiechnięta moc. Jednym ruchem odtrącam od siebie nagle to pijane z pragnienia i czarujące w swym braku konsekwencji zwierzę $(K, 162)$.

Janka nie wiedziała dlaczego, ale nagle, $\mathrm{w}$ trakcie pocałunków, odczuwała potrzebę „wyrwania się z zaciśniętych objęć” (K, 167). Nienawidziła Witolda, chciała, by odszedł, jednocześnie wiedząc, że to by ją zraniło.

Wszystkie trzy relacje — platoniczne uczucie do Rosławskiego, cielesna fascynacja Januszem oraz zdradziecka namiętność do Imszańskiego — to trzy kolejne próby inicjacji seksualnej. Zmysłowe spełnienie jednak zostało zakwestionowane, zahamowane i bohaterka wycofała się w dziewictwo, którego znakiem było symboliczne pytanie bohaterki: „czyż to po raz drugi chłodne, białe lilie zakwitły w moim opustoszałym ogrodzie?” (K, 219). Białe lilie, metafora czystości były dodatkowo chłodne, czyli pozbawione ciepła miłości, namiętności. Niespełnienie erotyczne w powieści utożsamiono zostało także ze śmiercią — symboliczną utratą marzeń i złudzeń („klękam u grobu marzenia. [...] I nigdy nie próbuję odwalić z grobu szarego kamienia ozdobionego czarną koronką przedwiekowych paproci”“11 - K, 218). Wydaje się, że bohaterka zdecydowała się na ostateczne zepchnięcie, ukrycie swoich potrzeb i pragnień.

Kolejne rozczarowanie, niespełnienie uczuciowe i zmysłowe oznaczało dla bohaterki powrót do „lodowych pól”, czyli niekochania, samotności, frustracji. Ten powrót przypieczętowany został zamknięciem się w klasztorze — oddaniem się pracy naukowej.

Ponieważ żaden związek nie spełnił potrzeb bohaterki powieści, nie okazał się dla niej satysfakcjonujący, zaś życie bez miłości wydawało się niemożliwe, Janka postano-

\footnotetext{
${ }^{41}$ Jak podały Borkowska i Kirchner (G. Borkowska, dz. cyt., s. 5; H Kirchner, Natkowska albo..., s. 833 — wyjaśnienie w przypisie 18), postać zimnego Rosławskiego należy utożsamiać ze Stanisławem Mędrzeckim, w którym Nałkowska kochała się jako młoda dziewczyna, zaś Witolda Imszańskiego z Leonem Rygierem, mężem pisarki, z którym małżeństwo okazało się rozczarowaniem i pasmem goryczy. „Szary kamień" byłby więc pamiątką po pierwszej miłości, którą Nałkowska zachowała do końca życia.
} 
wiła oddać się temu, co ma solidne podstawy. Dziewczyna była rozczarowana związkami, zawiedziona w swoich uczuciach, w przekonaniu, że miłość to życie. Nauka i rozumowe podejście wydawały się jej tym, na czym od tej pory będzie mogła budować swój świat, w którym uczucia zastąpi myśl, kierowanie się emocjami - myślenie analityczne i zdroworozsądkowe.

Grażyna Borkowska zupełnie słusznie wstęp do powieści z 1906 roku zatytułowała „Imperatyw miłości”. Miłość to w dziele Kobiety i w życiu głównej bohaterki ta siła, która nadawała bieg jej poczynaniom i refleksjom. Bohaterka podejmowała próby dookreślenia siebie i jednocześnie szukała mężczyzny, który pozwoliłby jej na pełną afirmację jej osobowości. Pieńkowska podała, że głównym tematem powieści jest miłość rozumiana jako „instrument samookreślenia się wobec świata i przeniknięcia sensu istnienia”42. Niemożliwe do pokonania pragnienie miłości w powieści zrealizowało się poprzez poszukiwania tego, który odpowie skomplikowanym, często przeciwstawnym potrzebom Janki.

Bohaterka to kobieta pobudzona erotycznie, zainteresowana seksualnością swoją i innych, a jednocześnie krępowana więzami cnoty, nieśmiałości, niepewności. Euforyczna, witalistyczna „wola” miłości, należąca do sfery instynktu, poddana została hamującemu działaniu ograniczającego spontaniczność i uczuciową swobodę rozumu, „intelektu” ${ }^{3}$. Ta antynomia intelektu i instynktu została zaczerpnięta przez Nałkowską z filozofii Artura Schopenhauera. Podczas gdy filozof kobietom nadał wybitną umiejętność posługiwania się instynktem ${ }^{44}$, nie rozumem, pisarka wyposażyła swoją bohaterkę także w intelekt. W ten sposób Janka, działając instynktownie, kierowała swe myśli na „ładne, rasowe zwierzę” (K, 21), jakim jest Janusz, zaś posługując się rozumem, uznaje Rosławskiego za jedynego godnego przeciwnika ${ }^{45}$ dla swojej inteligencji. Żadna z tych relacji nie okazała się wystarczająca.

Wielowarstwowość emocji kobiety zakochanej, złożoność uczucia ukazane zostały w relacji z Imszańskim. W tym romansie nie była już „albo, albo”, związek Dernowiczówny i Witolda pozwalał odczuć głównej bohaterce wariantywność, różnorodność odcieni miłości — od podziwu do pogardy, pragnienia i odrazy, uwielbienia i niechęci. W relacji z mężem Marty rządziło serce Janki. Okazało się jednak, że i tu bohaterka poniosła klęskę, zrównała się w cierpieniach z tymi kobietami, na których ból jeszcze niedawno patrzyła z ironią.

Janka zerwała relację z Witoldem, gdy stwierdziła, że to on jej nie kocha. Okazywało się więc, że, aby w miłości odnaleźć syntezę życia, dopełnienie siebie, uspokojenie w poszukiwaniach, potrzebna jest symetria — jednakowa siła, która ciągnęłaby dwoje ludzi do siebie.

\footnotetext{
${ }^{42}$ E. Pieńkowska, $d z$. cyt., s. 16.

${ }^{43}$ Tamże.

${ }^{44}$ A, Schopenhauer, Psychologia mitości, Warszawa 1903, s. 24; cyt. za: E. Pieńkowska, dz. cyt., s. 16.

${ }^{45}$ Miłość to dla Janki walka płci, zaś intelekt to broń pozwalająca ukazać swoją przewagę nad przeciwnikiem — mężczyzną. Nałkowska, pisząc powieść o kobiecie i z perspektywy kobiety, naturalnie nie posuwała się przy tym do mizogynicznych interpretacji Stanisława Przybyszewskiego i Augusta Strindberga, wystąpiła wobec nich polemicznie.
} 


\title{
„Ecce Femina!”
}

Powieść Kobiety to utwór o młodzieńczości i dojrzewającym umyśle, o niewinności i o budzącej się seksualności, o rozkosznej beztrosce dziecięctwa i pojawianiu się trosk, namiętności, sprzecznych emocji. Dzieło z 1906 roku ujawniło mieszaninę paradoksów, które można postrzegać jako sprzeczności istniejące w samej autorce przetransponowane na bohaterkę, realizację jej uczuciowej burzy oraz symbol niejednoznaczności płci kobiecej w ogóle. Pisarka ujawniła w Kobietach wiele ze swojego życia, ukazała proces dojrzewania, skomplikowaną drogę zyskiwania świadomości Janki Dernowiczówny, ale jednocześnie pokazała wędrówkę w dorosłość, miłość, przyjaźń, erotyzm każdej kobiety. Zuniwersalizowała ten proces, ale jednocześnie nie zabrała nic z jego indywidualności. Pokazała, jak dojrzewa młoda dziewczyna (dziś, wczoraj, jutro), zostawiając miejsce na to, co niedopowiedziane i niemożliwe - różne i specyficzne dla kobiety z początku XX czy XXI wieku. Nałkowska oddała codzienność dojrzewania — poszukiwania formuły na własną płeć w mieszaninie lęku, niepewności, wątpliwości oraz arogancji, szaleństwa i swobody. Ów melanż sprzeczności w rzeczywistości nie ma w sobie nic paradoksalnego ani przypadkowego. W każdej dojrzewającej kobiecie obok nieśmiałości jest zmysłowa ciekawość, a obok dziewczęcej niewiedzy — zaskakująca mądrość. Tym samym Nałkowska dobitnie zaprzeczyła poglądom Otto Weiningera, które przybliżyła Kirchner: „mężczyzna to myśl, kobieta — bez-myślność, mężczyzna indywidualność, kobieta nie ma osobowości ani właściwości”46. W kobiecie, według powieściopisarki, dojrzewa nie tylko ciało, płeć piękna to nie istota niższego rzędu, samica skupiona na realizacji potrzeb seksualnych, przeznaczona do spełniania jedynie funkcji rozrodczych. Nałkowska ukazała, że okres dojrzewania to czas narodzin kobiecej umysłowości, osobowości, charakteru, którego siła polega na znoszeniu bólu i rozczarowań w czasie poszukiwania miłości, niebędącej tylko złączeniem przedstawicieli dwóch płci, lecz także porozumieniem równorzędnych (ale nie jednakowych!) umysłów i temperamentów.

Anna Kaźmierska

\section{The Woman on the Threshold of Life. The Maturation to Love, Sexuality and Friendship IN THE Zofia NaŁKOWSKA's Novel WOMEN}

\author{
Summary
}

The debut novel by Zofia Nałkowska, entitled Women is a work about youth and maturation to life. The author is raising the motif, which is known and worked out in the literature of many periods, but she writes about it in an unique way. Firstly Nałkowska herself is on the threshold of life and career as a novelist. The consequences of that are the autobioghraphical signs, which are commented at the beginning of this paper. In the next paragraphs there are described the female hereos of the novel - young women,

\footnotetext{
${ }^{46}$ H. Kirschner, Natkowska albo..., s. 52; na podstawie: O. Weininger, Pteć i charakter, przekł. O. Ortwin, wstęp G. Kunigiel, posł. J. Prokopiuk, Warszawa 1994.
} 
who are excited with the life and its opportunities, as well as dissappointed with the painful lessons life gives them. This paper is trying to present the femininity "in statu nascendi" and its immaturity, naivety and narcissism. The complicated process of maturation is described with such elements like: looking for love, living in friendship and discovering body and people's sexuality as well as searching for a right way to live and think. This paper presents a lot of contrasts: naivety and arrogance, innocence and the strenght of desire, excitment and the tendency to analyse.

Słowa kluczowe: debiut zofii Nałkowskiej, kobiety u Nałkowskiej, młodość w literaturze, dojrzewanie w literaturze, XX-wieczna powieść

Keywords: Debut novel by Nałkowska, Woman by Nałkowska, youth in XX century literature, maturation in literature, XX centry novel 